\title{
Report on five species of harpacticoid copepods from vegetative area of Sungai Pulai, Johor
}

\author{
Zaleha Kassim a, ${ }^{*}$, Hazwani Hanim Hasnan a, Syazleen Zainal b, Nurul Huda Ahmad Ishak c \\ a Kulliyyah of Science, International Islamic University Malaysia, Jalan Sultan Ahmad Shah, Bandar Indera Mahkota, 25200 Kuantan, Pahang, \\ Malaysia \\ ${ }^{b}$ School of Fisheries and Aquaculture Sciences, Universiti Malaysia Terengganu, 21030 Kuala Terengganu, Terengganu, Malaysia \\ c School of Marine and Environmental Sciences, Universiti Malaysia Terengganu, 21030 Kuala Terengganu, Terengganu, Malaysia \\ * Corresponding author: drzack@iium.edu.my
}

\section{Article history}

Submitted 27 Feb 2018

Revised 28 March 2018

Accepted 30 April 2018

Published online 4 June 2018

\begin{abstract}
Bottom vegetation is known as preferred habitat for many types of meiofauna such as copepods. The conditions of sea bottom that include vegetation could contribute to the copepod's assemblage. Being an important diet for fish larvae, information on copepod species promotes effort for conservation of both fish species and marine ecosystem. Nonetheless, identification and taxonomic report on copepods from such areas are still scanty. Samples of copepods were collected by scrapping the uppermost $10 \mathrm{~cm}$ of sediment of bottom area at Sungai Pulai's seagrass-bed during low tide. Sediment was decanted to extract the copepods which later be preserved in $5 \%$ buffered formalin Body parts were dissected under microscope and prepared for taxonomic study. All drawings made with the help of Lucida tube were used for comparison with established key of identification. Five families were noted in this study; Ameridae Monard, Lang, Parastenhelia Thompson \& A. Scott, Dactylopusiidae Lang, Tisbidae Sars and Diosaccidae Sars. Harpacticoid copepod species described from this study were Ameira sp. (Ameridae Monard, Lang), Parastenhelia sp. (Parastenhelia Thompson \& A. Scott), Paradactylopodia sp. (Dactylopusiidae, Lang), Idyanthepusilla (Tisbidae, Sars) and Stenhelia sp. (Diosaccidae Sars). Further study on functional morphology would explain their adaptability to both conditions of sea bottom.
\end{abstract}

Keywords: Harpacticoid, Sungai Pulai, vegetative habitat

\section{INTRODUCTION}

Harpacticoid copepods are known as one of the preferred diets for marine larval and juvenile fish. Recently, investigation on the stomach content of larvae and juveniles fishes from the rocky shore in Portuguese coast proved the increase in composition of harpacticoid copepods following the increase size of the fish (Dias, Silva, Cabral, \& Vinagre, 2014). Earlier, it is also reported on the important of different species of harpacticoid copepods for marbled sole Pleuronectes yokohamae juveniles in the coastal area of Tsugaru Strait, Hokkaido. The usage of harpacticoid copepods as an important diet in larval rearing of some commercial fishes has been reported in a previous study (Olivotto et al., 2008). These findings support the idea of the important role of harpacticoid copepods in life cycle of fish.

In shallow or vegetation habitat, benthic harpacticoid copepods would swim vertically into the water column as their life-history strategy for dispersal. This behaviour improves their availability in the water column in which they are exposed to their predators; the fish larvae and juveniles. Thus, either on the benthic substrates or in the water column, benthic harpacticoid copepods become an important diet source for marine larval and juvenile fishes. Despite that, the information of species being preferred as fish diet is still lacking due to the lesser attention given to taxonomical and systematic studies of these preys.

It is hypothesized that Sungai Pulai estuarine area would support the phytals (harpacticoid lives on plant) or vegetative harpacticoids, and the epibenthic type (harpacticoid lives on bottom surface) found in the sediment. This investigation was made to identify some common benthic harpacticoids from the area. The information would contribute to the knowledge on these species as important diets of fish and other marine commercial species inhabiting Sungai Pulai coastal habitat.

Taxonomic study is in critical need of accurate species inventories. In order to explore the biodiversity of life, it is crucial to identify the species boundaries accurately as it determines whether or not the individual organisms that exist are related to the same entity. To date, there are 4300 species of harpacticoid identified (Wells, 2007) using traditional method of morphological differences. While there are also more advanced methods such as a combination of morphological and molecular approaches, the confusions arose from the morphological observations and the systematic notes on some families were due to the repetitive change of new reports and findings. Nonetheless, these basic methods are important as the foundation to separate different group and individual for many other studies.

The general structure of harpacticoid follows the description adopted by Huys and Boxshall (1991) where the major articulation divides the body into an anterior and posterior or be called as prosome and urosome (Huys \& Boxshall, 1991). The morphological characters including appendages on head, both rami of legs (leg 1 to leg 5) and spines (setae) distribution on each segment of the legs are particularly used to identify the species. The basic diagnostic characters could be found in the taxonomic works of previous researches (Lee \& Huys, 2002).

Some taxonomic notes on the species of harpacticoid copepods from Malaysia coast has been reported by Zaleha (2008) for 40 species. Following this report was identification of harpacticoids 
species associated with seaweeds in tide pool. The species were mostly from those adapted to both sediment and plant such as seaweeds as indicated by the pre-hensile and furiform shape. Researches on interstitial and phytal harpacticoid copepod at Datca and Bozburun, Turkey, also found the pre-hensile and furiformshaped harpacticoid of Parastenhaliidae and dorso-ventrally flattened of Dactylopusiidae on macroalgae Padina pavonica. A harpacticoid, Metamphiascopsis hirsutus, which has a pre-hensile body shape was also reported to inhabit seaweeds at Bidong Island intertidal zone The differences of sediment layer around seagrasses area could be used to determine the different of harapcticoid species.

In Sungai Pulai, Johor, a total of six Porcellidiidae species were recently reported from the seagrass bed (Zaleha, Jefri, \& Hasimah, 2013). Porcellidiidae species have oval dorso-ventrally compressed body shapes which enable them to attach tightly to seagrass's blade. The taxonomic report on other harpacticoid species found in the area is yet to be published. It will support the reports on abundance of their predators in the area such as fish larvae (Ara, Arshad, Musa, Amin, \& Kuppan, 2011) and shrimps(Arshad, 2011). In addition, planktonic copepods (copepods occupying water column) reported from this area showed high in abundance and diversity (Matias-peralta \& Yusoff, 2015). Thus, management plan for the important ecosystem such as Sungai Pulai seagrass area could become more comprehensive with the updates on the benthic group.

\section{EXPERIMENTAL}

\section{Methodology}

Field samplings were carried out during daytime when the sea has receded to its lowest level. A hand core (made of hollow PVC cylinder, diameter $3.5 \mathrm{~cm}$ ) was used to collect bottom sediment at the sampling stations in PulauMerambong, Kg. Pendas and Sungai Duku at the coastal area of Sungai Pulai (Figure 1). The hand corer was pressed onto the vegetative sediment down to $5 \mathrm{~cm}$ of the uppermost layer to collect a core sample. Sediment cores were immediately transferred into sampling bottle filled with $5 \%$ buffered formalin and brought to the laboratory for further processes.

In the laboratory, individual core was mixed with water and stirred carefully before decanted to extract all small invertebrates (meiofauna) trapped in the sediment. Decanted water was sieved through a series of 500 and 62 microns sieve. Those retained on the 62 microns sieve were considered as meiofauna and further isolated and sorted to collect harpacticoid copepods. Harpacticoids were rinsed for a few times with saline water and were placed with glycerol $(50 \%)$ medium on glass slide. A pair of insect pin was used to separate all body parts; cephalosome, prosome, urosome, legs (periopod, P), mouth parts and head appendages.

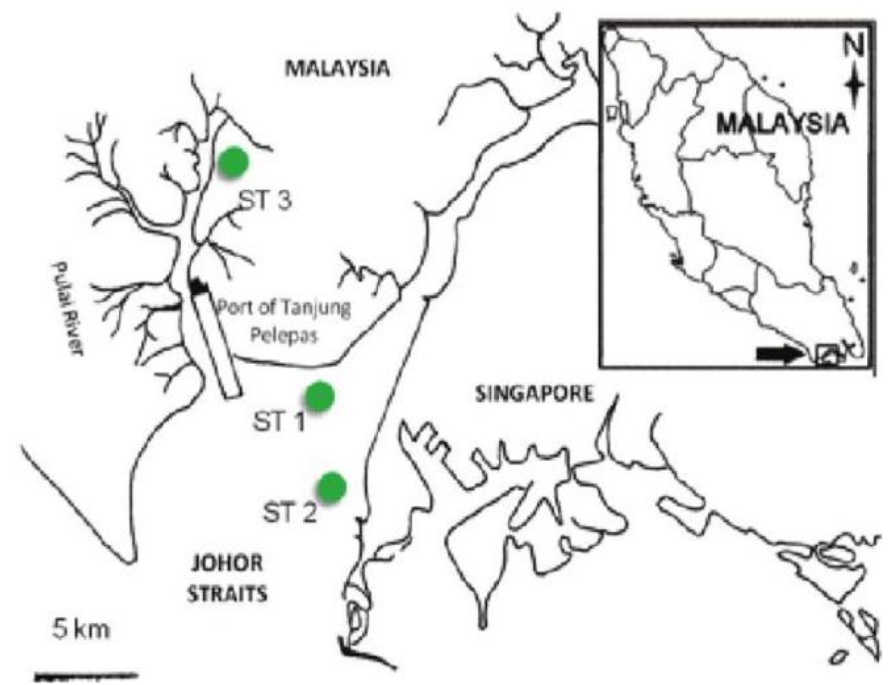

Figure 1. Study area at Sungai Pulai, the Straits of Johor, Malaysia. Note: ST $1=$ area of $\mathrm{Kg}$. Pendas; , ST 2= Merambong Island; ST $3=\mathrm{Sg}$. Duku.
Three major body parts which were prosome (upper body part), urosome (lower body part) and legs were first separated. Appendages found on the head part attached to urosome (antennule, antennae, mouth parts) were separated further. All of the body parts were placed on the same slide.

A drop of CMCP-9 was placed onto the slide as media and all of the dissected parts were put together on the same slide under a separate micro cover slip, and labeled. Fine structure of each parts was observed under a compound microscope (Olympus SZ7-LDB) attached with Lucida tube. Drawings were made from the image seen through the Lucida tube. Distribution of setae or bristles on each segment of leg 2, 3 and 4 were recorded to suggest the setal formula of the specimen.

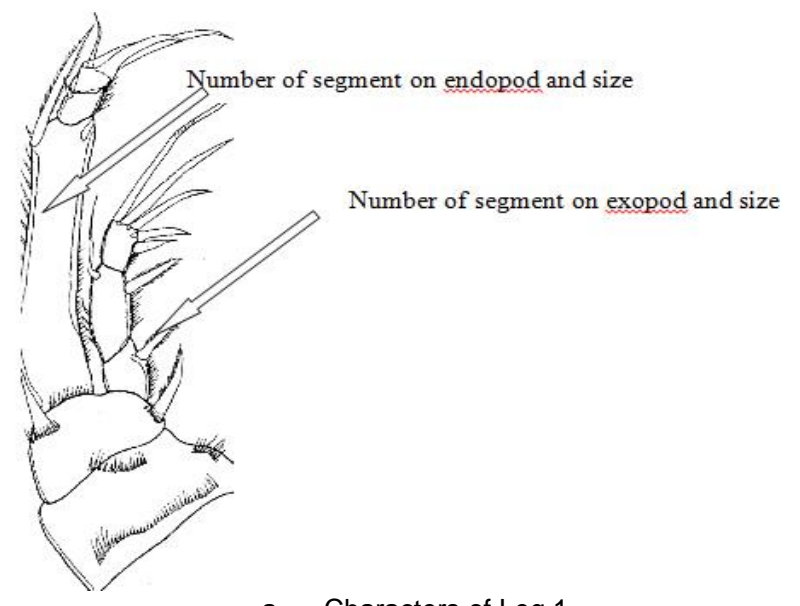

a. Characters of Leg 1

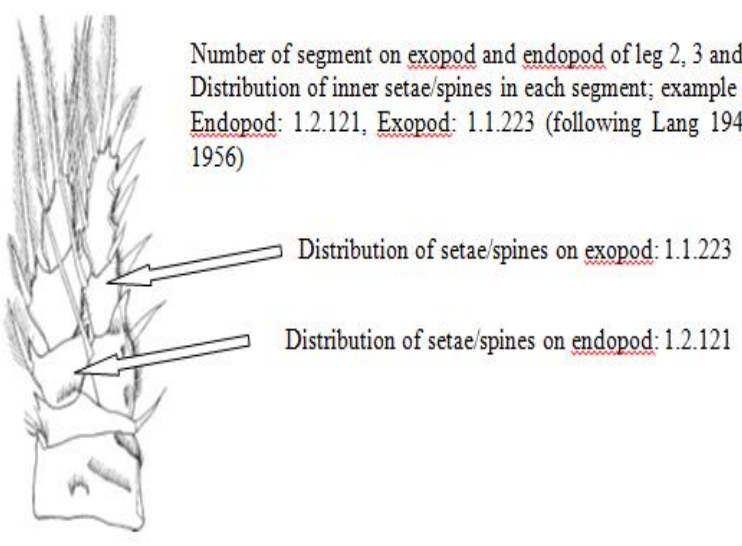

b. Distribution of spines (setae) on each segment of legs (setal formula)

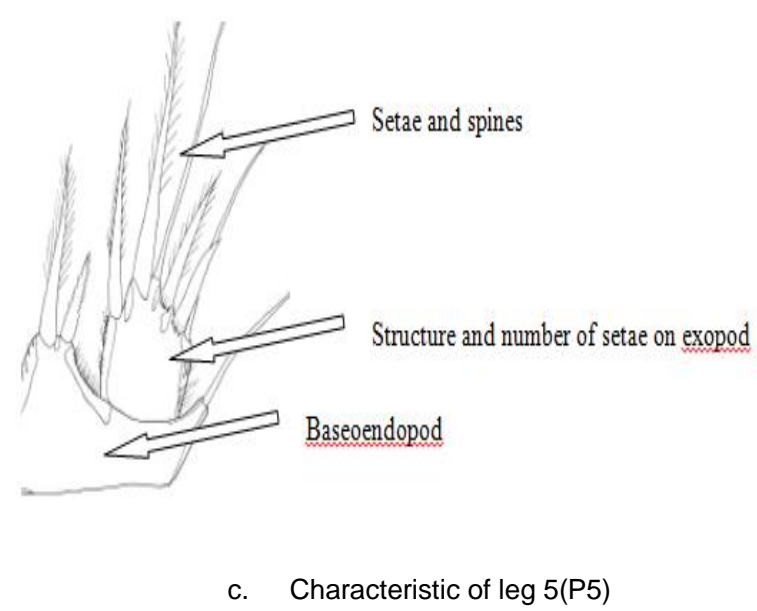

Fig. 2 Some diagnostic characters used for identification of harpacticoid copepod species. 
Species determination was based on the diagnostic characters such as found in the example (Figure 2). The main characters were the leg 1 , setal formula and leg 5 .

\section{RESULT AND DISCUSSION}

This study reported a total of five families of Harpacticoida which were represented by species as summarized in Table 1 .

Table 1. Summary of Family and Species of Harpacticoida from vegetative area of Sg. Pulai, Johor

\begin{tabular}{ll}
\hline Family & Species \\
\hline Ameridae Monard, Lang & Ameira sp. \\
Parastenhalliidae & Parastenhelia sp \\
Dactylopusiidae & Paradactylopodia oculata \\
Tisbidae & Idyanthe pusilla \\
Diosaccidae Sars. & Stenhelia sp. \\
\hline
\end{tabular}

\section{Ameridae monard}

Family: Ameridae Monard, Lang.

Genus: Ameira Boeck, 1864.

Species: Ameira sp.

Materials: sample obtained from Sg. Duku, Johor.

Body shape of the harpacticoid sample was slender with intermediate cephalothorax. The antennae or A1 was with 8 segments.

Leg 1 with 3 -segmented exopod. The exopod segment 2 was much shorter than the entire endopod segment 1 . The endopod had a claw-like structure for grasping or seizing. The endopod segment 1 was much longer than the segment 1 and 2 combined. The end of endopod was much wider than longer. Its exopod was without inner bristle and had 3 spines at the end.

Legs 2 to 4 have the following setal formula:

$\begin{array}{lll}\text { Leg } & \text { Exopod } & \text { Endopod } \\ \text { P2 } & 0.0 .122 & 0.1 .122 \\ \text { P3 } & 0.1 .123 & 1.1 .120 \\ \text { P4 } & 0.0 .012 & 1.1 .121\end{array}$

Leg 5 was with triangular-like exopod with 5 terminal bristle/setae. The baseoendopod's shape was more likely square in shape with 5 setae inserted at the terminal segment.

\section{Parastenhelliidae}

Family: Parastenhelliidae, nov.

Genus: Parastenhelia Thompson \& A. Scott

Species: Parastenhelia sp.

Materials: sample obtained from Sg. Pulai Johor. The harpacticoid sample obtained was female with attached eggs sac.

The body shape of the harpacticoid was slender and elongated (pre-hensile). The back of the body had the same length as the entire body. The antennae had 8 segments. Endopod of P1 had 2 segments while the exopod of the P1 has 3 segments. The P1's endopod 1 was much longer than the whole exopod. The exopod had 3 terminal setae.

Legs 2 to 4 were based on the following setal formula:

$\begin{array}{lll}\text { Legs } & \text { Exopod } & \text { Endopod } \\ \text { P2 } & 1.1 .212 & 1.1 .123 \\ \text { P3 } & 1.1 .122 & 1.1 .122 \\ \text { P4 } & 1.1 .121 & 1.1 .222\end{array}$

Leg 5 finely shaped with oval exopod. The baseoendopod had a square-like shape with 3 terminal setae inserted on it.

\section{Dactylopusiidae}

Family:Dactylopusiidae

Genus: Paradactylopodia, Lang.

Species: Paradactylopodiaoculata.

Materials: sample obtained from Sg. Pulai, Johor.
The body had long limbs. The shape of the body was slightly rounded but flattened. The posterior of the body was much narrower than the anterior. Abdominal segment was well developed. The exopod P1 had 3 segments. The entire exopod P1 was much shorter than the entire endopod. The endopod P1 had no segmentation. Both endopod and exopod had no inner bristle. The terminal segment of exopod 1 had 3 spines.

Leg 2 to 4 were based on the following setal formula:

$\begin{array}{lll}\text { Legs } & \text { Exopod } & \text { Endopod } \\ \text { P2 } & 1.2 .122 & -.0 .121 \\ \text { P3 } & 1.1 .1 .122 & 1.1 .021 \\ \text { P4 } & 1.1 .123 & 0.1 .122\end{array}$

Baseoendopod of P5 had square in shape with 5 terminal segment inserted on it. Exopod of P5 had 4 terminal setae with inner bristles.

\section{Tisbidae}

Family : Tisbidae

Genus: Idyanthe, Sars.

Species: Idyanthe pusilla.

Materials: obtained from Sg. Pulai, Johor.

General shape of the body was compact with the abdomen distinctly demarcated, somewhat narrower than the thorax. The cephalotorax had an ovoid shape and the abdomen length had the same length as the cephalotorax. The whole shape of the body was slightly curved. Antennule had 8 segments. The exopodP1 had 3 segments and its length was much shorter than the endopod1 of P1. The terminal segment of the P1 had 4 setae/bristles impaled on it. The end.P1 had 3 segments. The first segment of the end.P1 had the length of 3 segments of exopod P1 combined. Both rami did not have inner setae. The endopod P1 had claw like bristle at the end of it.

Leg 2 to 4 were based on the following setal formula:

$\begin{array}{lll}\text { Legs } & \text { Exopod } & \text { Endopod } \\ \text { P2 } & 1.1 .122 & 1.0 .121 \\ \text { P3 } & 1.0 .110 & 1.1 .122 \\ \text { P4 } & 1.1 .123 & 1.1 .122\end{array}$

The baseoendopod of P5 had 4 and the exopod had 5 protruding bristles. Exopod of P5 had a square-like shape.

\section{Diosaccidae Sars}

Family: Diosaccidae Sars.

Genus: Stenhelia Boeck, 1865.

Species: Stenhelia sp.

Materials: sample obtained from Kg. Pendas, Johor.

The body shape of the harpacticoid was laterally compressed but defined. The urosome was slightly elongated and narrow. The P3 of segment 2 had inner setae. Exopod had 3 members of segmentation. Exopod P1 consisted of 3 bristles protruding from its terminal segment. Endopod of P1 also had 3 members of segmentation. The first segment of endopod P1 was longer than the entire exopod. The terminal segment of endopod P1 had 3 setae and had claw-like structure for grasping.

Leg 2 to 4 were based on the following setal formula:

$\begin{array}{lll}\text { Legs } & \text { Exopod } & \text { Endopod } \\ \text { P2 } & 1.1 .121 & 0.0 .111 \\ \text { P3 } & 1.1 .121 & 0.0 .110 \\ \text { P4 } & 1.1 .223 & 1.1 .122\end{array}$

Exopod of P5 had 5 bristles with a square-like shape, while the baseoendopod had 5 bristles with irregular oval shape.

\section{Findings}

A total of five harpacticoid families were identified in this study. They were Ameridae, Parastenhalidae, Dactylopusiidae, Tisbidae and 
Diosaccidae. Ameridae and Parastenhalidae were originated from harpacticoid sample of Sungai Duku, which was a mangrove area. The other three; Dactylopusiidae, Tisbidae and Diosaccidae, were obtained from seagrass bed either at Merambong or $\mathrm{Kg}$. Pendas. It was pointed out that the assemblage and composition could be related to the habitat complexity and vegetative bottom (Mascart et al., 2015). Nevertheless, none of the Porcellidiidae species reported in this study was contrary to the earlier report (Zaleha et al., 2013). Sampling method adopted in the present study which was more focused on the near sediment surface possibly left out the harpacticoids attached to bigger seagrass blades.

Ameira sp. found in this study had the morphology appearance of slender body shape and intermediate cephalotorax, which was similar as Nitocra of the same family. Nitocra sp. was reported to inhabit both seaweed and sediment of the rock pool of Pulau Besar, Melaka, while Nitocra sp. found in Teluk Gadung, Pangkor Island inhabited intertidal sediment. The characteristic of leg 1 or P1 of Ameira sp. which had elongated endopod segment 1 and claw-like structure at the terminal end might be important appendage to enable them to cling on the blade of seagrass. Vegetation such as mangroves and seagrasses contributed to the better condition of bottom sediment for harpacticoids and other meiobenthos (Zaleha et al., 2013).

For the family Parastenhaliidae, species of harpaticoid found was Parastenhelia sp. The body shape was slender and elongated. The urosome had the same length as the prosome. This was different from Parastenhelia sp. previously found in intertidal sediment of Tanjung Tuan, Port Dickson which also had elongated body but with a large rostrum (Zaleha, 2008), even though they shared the same characters of leg 1. The species found was confirmed to belong to the same family, but with different setal formula. Zaleha et al. (2010) also identified Parastenhelia littoralis from the seaweeds and bottom sediment of their study area (Zaleha et al., 2010). A research on interstitial and phytal harpacticoid copepod on Datca and Bozburun, Turkey, also identified family Parastenhaliidae on the macroalgae Padina pavonica (Alper, Karaytu, \& Sak, 2010).

Family Dactylopusiidae was represented by Paradactylopodia oculata which was obtained from seagrasses at Merambong. As reported before (Alper et al., 2010) family Dactylopusiidae might be found in interstitial and macroalgae habitat. Their existence in both vegetation and sediment would be in agreement with the earlier reports. Dactylopusia euryhalina was reported to colonize and inhabit sandy sea bottom which was been dredged via weak transport movement of algal mat to the area ${ }^{17}$. Dactylopusia and Paradactylopusia species which had been identified as phytal species was also reported to inhabit coral fragments along with other sediment-dwelling forms such as Ameira, Ectinosoma and Amphiascus species (Huda \& Zaleha, 2009). The morphology of the family Dactylopusiidae enables them to survive in a variety of coastal habitat. Existence of this species with their specialized morphological structure enable them to survive within Sungai Pulai Johor which had most extensive seagrass bed, large portion of pristine mangrove forest and some coral reef (Zaleha, Diyana, Kamaruzzaman, \& Akhbar, 2015). It could be a common group in other tropical vegetative sediment such as in Gazi Bay seagrass zone (Kenya) and occurred along with Laophontidae and Diosaccidae (De Troch, Fiers, \& Vincx, 2003).Unfortunately, this family was not found in protected areas of Andaman and Nicobar Islands in which other families of Canuellidae, Cylindropsyllidae, Diosaccidae, Ectinosomatidae, Laophontidae, Longipediidae, Parastenheliidae, and Tetragonicipitidae became common (Jayabarathi, Padmavati, \& Anandavelu, 2015).

Family Tisbidae was represented by Idyanthe pusilla. Most of the species from family Tisbidae were a phytal and benthic species on vegetation such as mangroves and seagrasses(Zaleha et al., 2015). The presence of this group in Malaysia water was not notified before. There were Idyanthe tellena Brady, Idyanthe australis, Idyanthe dilatata (G.O. Sars, 1905) and Idyanthe pusilla Sars recorded so far in the world and none from Malaysia.

Species represented Diosaccidae was Stenhelia sp. This family is usually represented by epiphytic, phytal or epibenthic species which has dorso-ventrally compressed, extremely rounded or broadened cephalosome. The characteristics of the leg 1 were much more the same to the family Tisbidae due to its habitat. Diosaccidae could be the more adaptable group to both vegetation and sediment habitat as reported on their abundance on intertidal zone as well as vegetative subtidal area (Leduc \& Probert, 2011). Obviously, the co-occurrence of phytal group such as Tisbidae and Dactylopusiidae and sediment group such as those from Ameiridae and Diosaccidae indicated the importance of habitat space and complexity in the study area (Gheerardyn et al., 2008).

\section{CONCLUSION}

Five families were reported from this study, which were family Ameridae, Parastenhallidae, Dactylopusiidae, Tisbidae and Diosaccidae. They showed unique and different characteristics which suit and related to their occurrence habitat. Body morphology, shape and the characteristics of the leg 1 or P1 indicated their adaptation for movement on the substrate such as vegetation and sediment. Nonetheless, differences in some characters did not limit their coexistence in Sungai Pulai estuary. Further species identification and ultra-structure observation could provide an insight on the harpacticoids copepod distribution in different habitat of $\mathrm{Kg}$. Pendas and Merambong vegetative areas and Sungai Duku which will improve the concern on the crucial of vegetation in protecting the coastal ecosystem.

\section{ACKNOWLEDGEMENT}

This research is supported by Research Initiative Grant Scheme (RIGS 16-315-0479) International Islamic University Malaysia awarded to the first author.

\section{REFERENCES}

Alper, A., Karaytu, S., Sak, S. 2010. Interstitial and phytal harpacticoida (crustacea : Copepoda) inhabiting the mediolittoral zone of the datçabozburun peninsulas (Muğla, Turkey). SDU Journal of Science, 5(1), 1628. Retrieved from: http://fenbilder.sdu.edu.tr/english/makale5-1/fef3.pdf

Ara, R., Arshad, A., Musa, L., Amin, S. M. N., Kuppan, P. 2011. Feeding habits of larval fishes of the family clupeidae (actinopterygii: Clupeiformes) in the estuary of River Pendas, Johor, Malaysia. Journal of Fisheries and Aquatic Science, 6(7), 816-821.

Arshad, A. 2011. Influence of environmental parameters on shrimp post-larvae in the Sungai Pulai seagrass beds of Johor Strait, Peninsular Malaysia. Scientific Research and Essays, 6(26), 5501-5506. doi:10.5897/SRE11.694

De Troch, M., Fiers, F., Vincx, M. 2003. Niche segregation and habitat specialisation of harpacticoid copepods in a tropical seagrass bed. Marine Biology, 142(2), 345-355. doi:10.1007/s00227-002-0958-7

Dias, M., Silva, A., Cabral, H., Vinagre, C. 2014. Diet of marine fish larvae and juveniles that use rocky intertidal pools at the Portuguese Coast. Journal of Applied Ichthyology, 30(5), 970-977.

Gheerardyn, H., De Troch, M., Ndaro, S. G. M., Raes, M., Vincx, M., Vanreusel, A. 2008. Community structure and microhabitat preferences of harpacticoid copepods in a tropical reef lagoon (Zanzibar Island, Tanzania). Journal of the Marine Biological Association of the UK, 88 (04), 747-758. doi:10.1017/S0025315408001331

Huda, A. I. N., Zaleha, K. 2009. Taxanomy of a benthic copepod: Methamphiascopsis hirsutus (Thompson \& A. Scott, 1903) (harpaticoida: Diosaccidae) from Bidong Island, Malaysia. Malaysian Journal of Microscopy, 5(1), 36-41.

Huys, R., Boxshall, G. A. 1991. Copepod Evolution (Vol. 159). London: The Ray Society.

Jayabarathi, R., Padmavati, G., Anandavelu, I. 2015. Spatial heterogeneity of benthic copepods: A comparative aspect on composition, abundance, and correlation. Zoological Studies, 54: 51. doi:10.1186/s40555-015-0130-y

Leduc, D., Probert, P. K. 2011. Small-scale effect of intertidal seagrass (Zostera muelleri) on meiofaunal abundance, biomass, and nematode community structure. Journal of the Marine Biological Association of the United Kingdom, 91(03), 579-591. doi:10.1017/S0025315410001645

Lee, W., Huys, R. 2002. A new genus of groundwater ameiridae (copepoda, harpacticoida) from boreholes in Western Australia and the artificial status of stygonitocrella petkovski, 1976. Bulletin of The Natural History Museum. Zoology, 68(01), 39-50. doi:10.1017/S0968047002000055 
Mascart, T., Lepoint, G., Deschoemaeker, S., Binard, M., Remy, F., De Troch, M. 2015. Seasonal variability of meiofauna, especially harpacticoid copepods, in Posidonia oceanica macrophytodetritus accumulations. Journal of Sea Research, 95, 149-160. doi:10.1016/j.seares.2014.07.009

Matias-peralta, H. M., Yusoff, F. 2015. Status of planktonic copepod diversity in the Merambong Seagrass Meadow, Johor, Peninsular Malaysia. International Journal of Ecosystem, 5(2), 39-43. doi:10.5923/j.ije.20150502.01

Olivotto, I., Capriotti, F., Buttino, I., Avella, A. M., Vitiello, V., Maradonna, F., et al. 2008. The use of harpacticoid copepods as live prey for Amphiprion clarkii larviculture: Effects on larval survival and growth. Aquaculture, 274(2-4), 347-352. doi:10.1016/j.aquaculture.2007.11.027
Wells, J. B. J. 2007. An annotated checklist and keys to the species of Copepoda Harpacticoida (Crustacea). Zootaxa 1568, 1-872.

Zaleha, K. 2008. A pictoral guide to some marine harpaticoid copepod of Malaysia. Kuala Terengganu: UMT Publisher.

Zaleha, K., Diyana, M. F. F., Kamaruzzaman, Y. B., Akhbar, B. J. 2015. Meiobenthic community in vegetative areas at Sungai Pulai estuary. Malayan Nature Journal, 67(1), 1-14.

Zaleha, K., Jefri, A. M. A., Hasimah, M. S. 2013. Fauna of porcellidiidae (Copepoda: Harpacticoida) from Sungai Pulai, Malaysia. Malayan Nature Journal, 64(4), 159-167.

Zaleha, K., Nazia, A. K., Huda, A. I. N. 2010. Species assemblages of benthic harpaticoid copepods on tide rock pool seaweeds of Pulau Besar, Melaka, Malaysia. Journal of Tropical Biology and Conservation, 7, 1-10. 